TAX LAW IMF TECHNICAL NOTE $\underset{\substack{\text { voumm } \\ 0112019}}{1}$

\title{
DESIGNING INTEREST AND TAX PENALTY REGIMES
}

Christophe Waerzeggers । Cory Hillier I Irving Aw

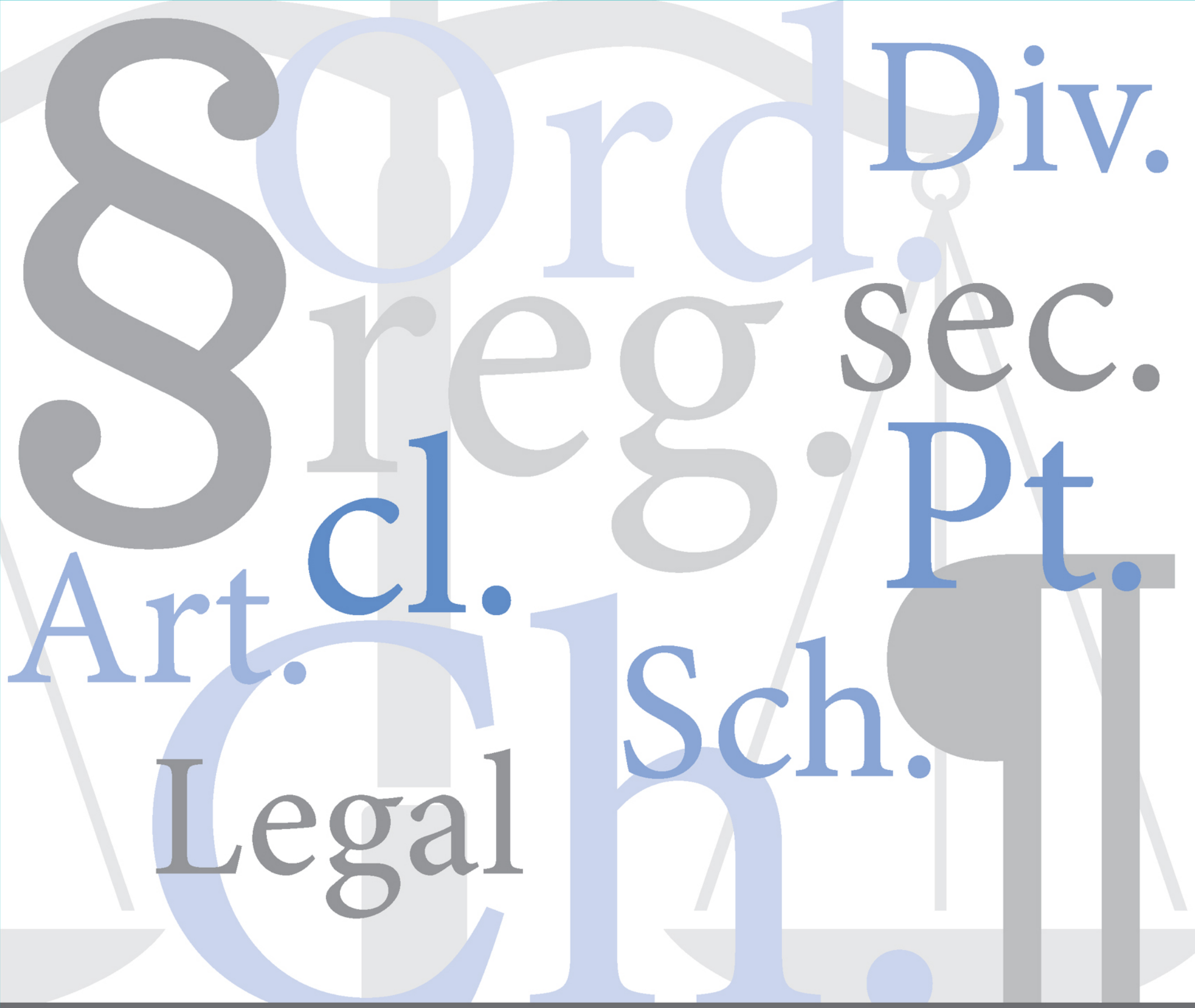


TAX LAW IMF TECHNICAL NOTE $\underset{\substack{\text { volumi } \\ 0112019}}{1}$

\section{DESIGNING INTEREST AND TAX PENALTY REGIMES}

Christophe Waerzeggers । Cory Hillier I Irving Aw

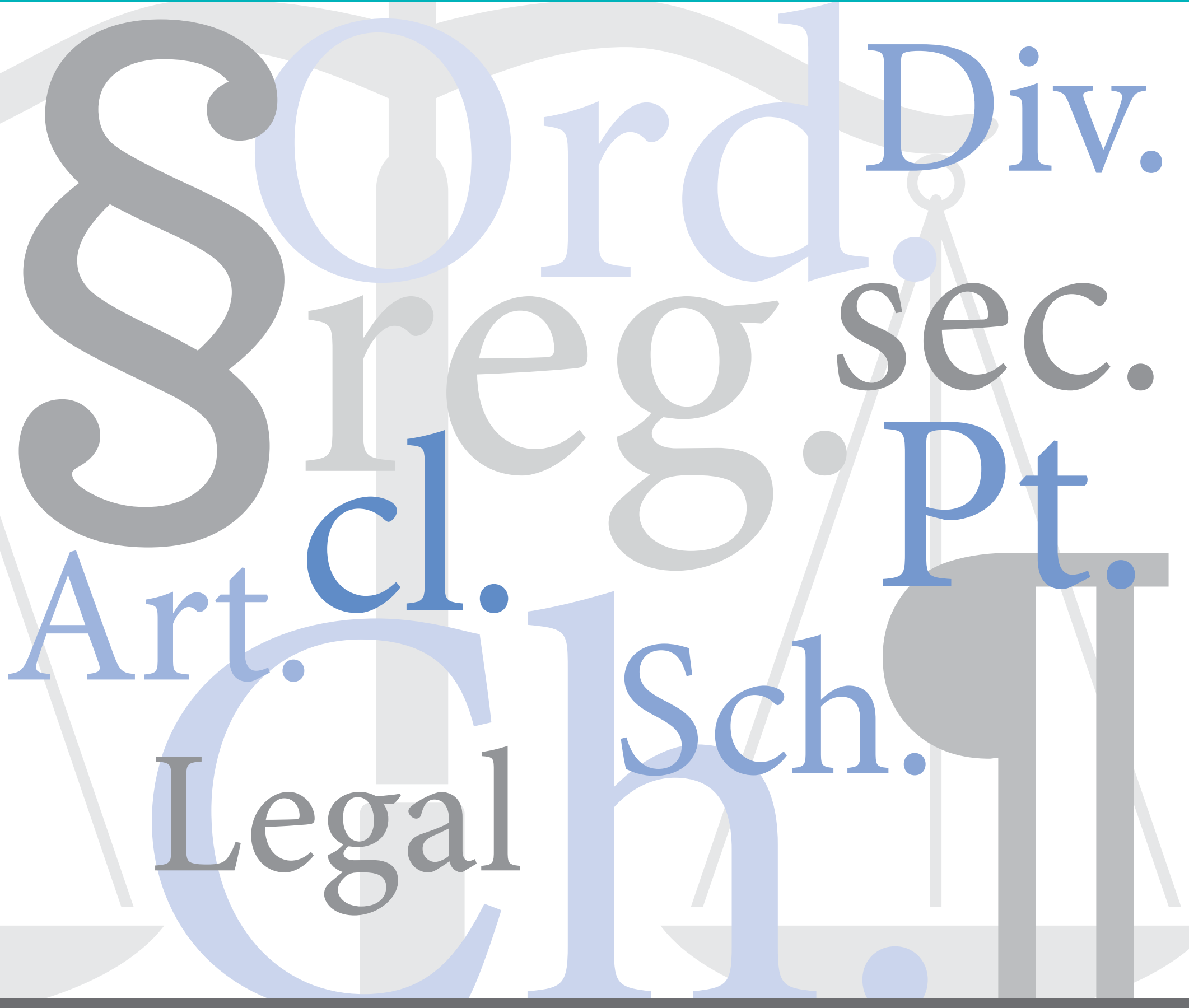


January 2019

Waerzeggers, Christophe, Cory Hillier, and Irving Aw, 2019, “Designing Interest and Tax Penalty Regimes", Tax Law IMF Technical Note 1/2019, IMF Legal Department

This Tax Law Note was prepared by the tax counsels of the IMF's Legal Department. This Tax Law Note should not be reported as representing the views of the IMF. The views expressed in this Tax Law Note are those of the authors and do not necessarily represent those of the IMF or MF policy.

\section{CInternational Monetary Fund. Not for Redistribution}




\title{
DESIGNING INTEREST AND TAX PENALTY REGIMES
}

\author{
Christophe Waerzeggers, Cory Hillier, and Irving Aw'
}

\section{OVERVIEW}

Nearly all tax systems have some form of interest and tax penalty regimes. Interest payable on any late or underpayment of tax seeks to protect the present value of the tax amount to the government budget, whereas penalties are intended to deter taxpayers from defaulting on their tax obligations-and to punish them if they do-to achieve horizontal equity vis-à-vis compliant taxpayers. As interest and penalties serve very different objectives, they should not be applied in a mutually exclusive manner.

This note focuses on the key issues that should be taken into consideration in designing interest and penalty regimes in tax legislations.

\section{EXECUTIVE SUMMARY}

The primary objective of an interest regime is to protect the present value of tax revenues by compensating the government for the deprivation of use of tax amounts that are not paid on time. Interest should therefore accrue automatically from the time the liability arises, without the need for an assessment and regardless of any extension in time given by the tax authority for payment under any installment scheme or other flexible payment arrangement. Late payment by taxpayers should be subject to an interest rate higher than commercial lending rates to ensure that taxpayers will accord priority to tax debts over other debts they may have. The responsibility in paying withholding taxes in a timely manner rests with the withholding agent, and any late payment interest payable in respect of withholding taxes should be borne by the withholding agent, who should not be allowed to recover such interest from the recipient of the payment subject to withholding.

In designing an interest regime, sufficient consideration should also be given to ensure that taxpayers' interests are adequately protected. International good practices in relation to the protection of taxpayers' interests include clarity in the computation of interest payable (including whether interest is computed daily or monthly), informing taxpayers that interest has accrued and continues to accrue on the outstanding tax debt (although the accrual of interest should be automatic and is independent of such notification to taxpayer), as well as a corresponding right to be compensated if there is overpayment of tax (but at commercial or a lower rate and only if there is unnecessary delay by the tax authority in making repayment). A sample set of provisions establishing an interest regime is set out in Appendix A.

The main objective of a tax penalty regime, on the other hand, is to encourage or compel taxpayer compliance. Effectiveness is therefore key in the design of a tax penalty regime, and should be considered along two lines:

(a) identifying the types of rights and benefits that taxpayers of a particular profile are likely to cherish or value and limiting access to those rights and benefits in case of non-compliance; and (b) whether a particular infraction is more appropriately sanctioned by the tax authority or the criminal justice system, taking into account, inter alia, their 1 The authors acknowledge the benefit of comments received from Wouter Bossu of the IMF's Legal Department and from Juan Toro, Katherine Baer,
Margaret Cotton, Lucilla McGlaughlin, Patrick De Mets and Miguel Pecho of the IMF's Fiscal Affairs Department. 
respective available resources and the gravity of the infraction. A common tax penalty regime should apply across all tax types for consistency and fairness. A sample set of provisions establishing a tax penalty regime is set out in Appendix B.

\section{As different taxpayers are motivated by different} considerations, an effective tax penalty regime should comprise of a variety of sanctions-both monetary and non-monetary. There are basically three ways to design monetary penalties: (a) fixed penalties (which are suitable for cases where the behavior being penalized has an indirect connection with the underpayment of tax such as where there is a failure to provide a requested document); (b) percentage penalties (which are based on a percentage of tax underpaid or the income of the person and are particularly useful in cases involving larger taxpayers where a fixed penalty may not be appropriate or effective in promoting compliance); and (c) graduated penalties (which are suitable where the infraction involves varying degrees of culpability or where the taxpayer engages in inappropriate behavior repeatedly). Graduated penalties can be designed in a predetermined manner, and/or exercisable on a discretionary, case-by-case basis by the tax authority, with a view to achieving a fair result such that the severity of the sanction is proportional to the level of culpability of the offender.

An effective tax penalty regime should also contain a variety of non-monetary sanctions to encourage compliance in cases where monetary sanctions are ineffective by depriving taxpayers of rights and benefits that are of greater economic or personal significance to them than money. Common forms of non-monetary sanctions include restrictions on taxpayers' freedom of movement (with appropriate taxpayer safeguards) or on their ability to engage in business or profession, as well as criminal convictions, or more simply the naming and shaming of recalcitrant taxpayers. Non-monetary sanctions should be carefully designed to ensure that they do not inadvertently impede taxpayer's ability to pay tax; for example, a taxpayer can be given a grace period to make payment before non-monetary sanctions are imposed. Where the enforcement of a non-monetary sanction involves another government department or agency, an assessment of the capacity for interdepartmental or interagency cooperation should be made to ensure the effectiveness of the sanction.
The legal design of a tax penalty regime should also consider if a particular infraction is more appropriately sanctioned by the tax authority or the criminal justice system, or both (subject to any restrictions under the constitution and legal traditions of individual jurisdictions, including human rights laws). Administrative penalties are generally easier to apply and less expensive to impose than criminal penalties. Therefore, taking certain types of infractions out of the criminal justice system can improve the expediency and consistency in treatment, and may be especially valuable where a jurisdiction's criminal justice system is already overburdened. Consistent with the principle of fairness, criminal penalties should be reserved for the most serious offences involving fraud or evasion (i.e. blameworthy behavior that deserves punitive actions) or behavior that in the aggregate amounts to fraud or evasion (for instance, repeated failure to file tax returns could attract a rebuttable presumption of intent to evade tax), where the punitive nature of criminal penalties are appropriate.

It should be noted that the legal design of penalties is an important but not the only relevant factor in achieving tax compliance. Other factors include the effectiveness of both domestic and international exchange of information frameworks, the availability of analytical detection models, data matching and risk profiling capacities, effective tax audits, and community reporting. There is also an increasing trend in encouraging voluntary disclosure by taxpayers in reporting underpayment of taxes and previous breaches of tax laws through reductions in tax penalties and other incentive regimes.

In the design of both interest and tax penalties, there is a clear need to ensure fairness and certainty for taxpayers. In this regard, it is common for tax authorities to be given discretion to separately remit or waive all or part of the interest or penalties imposed in limited and clearly prescribed circumstances, with appropriate accountability mechanisms to ensure that the discretion is exercised in an equitable and consistent manner.

The remainder of this note is organized as follows. Section III sets out the justifications for imposing late payment interest and tax penalties as well as general considerations in their designs. Sections IV and V set out the best practice design features of an interest regime and a tax penalty regime respectively. 


\section{JUSTIFICATIONS FOR TAX INTEREST AND TAX PENALTIES AND GENERAL DESIGN CONSIDERATIONS}

Interest on tax underpaid is justified on the basis that taxpayers are depriving the government of the potential earning capacity on the amount underpaid. Interest is therefore compensatory in nature as it seeks to compensate the government budget for the deprivation of the earning capacity of the amount underpaid. ${ }^{2}$

On the other hand, tax penalties are typically justified on grounds of deterrence. Tax penalties are often intended to achieve greater compliance by deterring certain undesirable behavior-and exacting punishment when such behavior does occur. Under a rational choice theory, taxpayers are reasoning actors who will comply with their tax obligations if the cost of non-compliance exceeds any savings therefrom. Therefore, tax penalties, when properly designed, executed and enforced, should have the effect of deterring taxpayers from errant behavior. ${ }^{3}$

Tax penalties can also be justified on retributivist grounds for failure to fulfill one's civic and social responsibilities. Under such a theory, penalties are justified on the basis that the duty to pay tax has been breached, and that there is something blameworthy in the taxpayer's failure to comply with such duty. Conversely, taxpayers should not be punished if they are not at fault or have acted reasonably, including by adopting a reasonable interpretation of the law even where it differs from the tax authority's interpretation.

When designing an effective tax penalty regime, it is therefore critical to understand what motivates taxpayers to comply with their tax obligations. Taxpayers can be expected to comply more readily with their tax obligations in circumstances where the expected benefits of that compliance outweigh the expected costs,

\footnotetext{
2 Some countries instead choose to impose additional fines or charges-sometimes referred to as "default surcharges"-in lieu of interest to compensate for the time value of money.

3 Tax penalties are by no means the only way to achieve tax compliance. There are other compliance strategies that are not based on deterrence. For instance, in some countries, a good compliance track record is a prerequisite for the taxpayer to avail itself of favorable treatment (for instance, compliant taxpayers may be allowed to defer payment of VAT/ GST on importation of goods to their periodic tax return to alleviate cash flow costs). More recently, several countries have further finetuned their compliance strategies by drawing on research in the field of behavioral economics. For a more comprehensive discussion on tax compliance strategies, see International Monetary Fund (IMF), 2015, "Current Challenges in Revenue Mobilization: Improving Tax Compliance", IMF Policy Paper (Washington: International Monetary Fund).
}

and where compliance adheres more closely to social or personal norms. This means that tax penalties can be more effective when they also include a threat of feelings of guilt or shame (as compared to the mere threat of legal sanctions). This underscores why a penalty regime can be more effective when combined with education, tailored communication and/or rewards. A more comprehensive tax penalty regime would also typically make taxpayers responsible for the actions of their agents. It may also contain a separate set of penalties for promoters of tax avoidance schemes.

Due regard should be given to any requirements or limitations imposed by constitutional law, administrative law, human rights law, and other relevant international and domestic legal obligations, whether in designing interest regimes or tax penalty regimes. Often, there are constitutional and other legal limits on how interest and penalties can be designed. For example, some constitutions prohibit the imposition of excessive fines. Constitutions may also provide for a right to freedom of movement, which may prevent the ability for tax administrations to issue travel restriction orders against certain errant taxpayers. Other relevant constitutional or international law principles that would typically need to be taken into account include the prohibition of double jeopardy (or non bis in idem) according to which a person cannot be punished twice for the same offence, as well as preserving the right to have the matter of the imposition of tax related penalties dealt with by the authorities without unreasonable delay while maintaining appropriate access to a judicial review process.

Where the tax penalty regime involves the exercise of broad discretionary powers in making administrative penalty decisions, consideration should also be given to the question of who is empowered to exercise such discretion. In a modern tax administration, the authority to impose penalties for non-compliance with tax laws is commonly vested in the Commissioner or DirectorGeneral, who then delegates such powers to appropriate senior officials within the tax administration. Such delegation of powers should be accompanied by appropriate safeguards to ensure consistency in application of powers and accountability, such as having clear and transparent guidelines on the circumstances in which penalties payable 
will be increased, decreased or remitted, and providing for taxpayers' ability to object to the imposition of penalties that are inconsistent with such guidelines.

Finally, the tax law framework should be designed and drafted so that each statutory obligation that is imposed by that framework is enforceable in some way. That does not mean that each failure to perform the obligation should necessarily attract a penalty. In some cases, the appropriate result may be for the tax authority to pursue another compliance remedy. However, for each requirement in the law, there should be some enforcement or compliance step that can be taken if the requirement is not met.

\section{BEST PRACTICE DESIGN FEATURES FOR INTEREST REGIME}

A sample generic provision for late payment interest is set out in Appendix A. The sample provision is general in nature and simplified, and does not take into account the individual circumstances of any particular tax and broader legal system. The ultimate form of any late payment interest provision to be adopted by a given country should take into account the country's specific legal tradition and system - including any constitutional and other domestic law limitations - as well as its political and administrative structure and fiscal policies.

\section{A. Accrual of Interest}

It is not uncommon for the law to provide for interest to accrue on an automatic basis. While the law may also provide for the tax authority to make a formal assessment of the amount of interest that has accrued up to a certain point in time for the purpose of notifying the taxpayer or to facilitate recovery, such an assessment should not be a pre-condition to the interest becoming payable. In other words, no assessment should be required to impose an interest liability. However, the ability to enforce and collect the interest liability that accrues automatically will be subject to any statute of limitations that applies for raising an assessment against the taxpayer to which the interest relates.

Particular challenges arise for tax regimes that provide for payment of tax by periodic installments-for example, quarterly - with an annual reconciliation. These regimes may adopt different design features when separately imposing penalties and interest. For example, the risk of underreporting in periodic installments may be addressed through penalties that apply to deliberate or careless underreporting, or where the difference between the estimate and the actual exceeds a specified threshold (for example, 20 percent). Interest should, of course, accrue for reported installments that are not paid in a timely fashion and to late payments of the amount due after the annual reconciliation. Where installments are deliberately or carelessly underreported, interest could also be imposed using adjusted instalments amounts, calculated back to the original installment payment due dates.

It is good practice to specify in the law precisely how interest is to be calculated-for example, on daily or monthly balances. For example, under Australian law, late payment interest is computed on a daily compounding basis. A compounding daily basis is more complex but might be regarded as the most theoretically appropriate to compensate for the lost time value of money, while the complexity is of less importance when calculations are automated. The law should specify the basis of calculation with precision to avoid uncertainty and disputes. The sample generic provision for late payment interest in Appendix A provides for late payment interest to be computed on a compounding daily basis. When prescribing the calculation of late payment interest, the liability should run from the date the tax first becomes payable (and determined without regard to an extension of time that may have been granted) until the date the late payment is made. The calculation period should ignore any permitted extensions of time on the basis that the effect of an extension of time is to protect the taxpayer from a liability for late payment penalty but not late payment interest. As discussed further below, jurisdictions should have the power to remit part or all of the interest on late payments, which could be exercised where unique and limited circumstances exist that make it fair and reasonable to do so. In the case of an adjusted assessment, late payment interest should run from the date on which the tax becomes payable under the original assessment, commonly referred to as the original due date. 


\section{B. Rate of Interest}

It is common for the rate of interest for underpayment or late payment of taxes to be higher than commercial lending rates. At a minimum, the rate of interest that is charged on an underpayment or late payment needs to compensate the government budget for the lost time value of the money had the payment been made on the relevant due date. While the interest rate should not be set so low so as to encourage taxpayers to use the government as a lending institution (for instance by using tax arrears as alternative form of finance), the rate should also not be set so high so as to be punitive. Many countries therefore try to approximate market interest rates by adopting an interest rate based on the central bank lending rate or an index of commercial lending rates and by adding some fixed percentage points to that rate. The interest rate should also be adjusted periodically and sufficiently frequently (such as quarterly) to reflect market developments, but not so frequently as to complicate administration. For example, Australia imposes a general interest charge on outstanding tax assessments at the bank bill rate plus 7 percent, with a lower uplift factor of 3 percent applying in the period before a reassessment is made by the tax authority. If the interest rate was set at or below commercial lending rates, taxpayers would be more likely to pay other creditors before they pay their taxes, since taxpayers would prefer to pay debts to their financial creditors to avoid breaching covenants or denial of credit, and to their suppliers to ensure continued availability of stock or services.

On the other hand, overpaid taxes are often refunded with interest at or below ordinary commercial lending rates. While at first glance it may appear inequitable for a higher interest rate to apply to underpayments of tax than to overpayments, there are sound policy reasons for the distinction. Taxpayers should not be rewarded with higher than commercial rates of interest for overpayments, as the commercial rate is a proper estimation of their loss. Moreover, if interest on overpayments exceeds the commercial rate, taxpayers will choose overpayment as a favorable form of investment at the detriment of the revenue. Also, governments are generally assumed to be of better credit standing than the standard debtor, which justifies a lower interest rate. It is also common to limit the payment of interest on refunds of overpaid taxes to a situation involving an unnecessary delay by the tax authority when making the refund payment. For example, the tax law framework could state that no interest is payable in respect of a refund of overpaid taxes where the refund is paid within a prescribed period (for instance, 60 days) of the taxpayer applying for the refund. This means that any delay in the payment of the refund by the tax authority would need to exceed the specified period before the taxpayer becomes entitled to interest on the refund.

\section{Remission of Interest}

Because interest on underpayments is designed to compensate the government budget for the lost time value of money, it is generally not appropriate to remit or reduce any interest accrued. However, jurisdictions may remit all or part of the interest on underpayments in limited circumstances. This is usually where the reason for the late payment is beyond the control of the taxpayer, such as natural disasters, serious injury, unexpected serious health issues or technology failures.

\section{Where the tax authority has the power to remit} both interest and penalties, that power should be exercisable separately in respect of either interest or penalties. The ability to separately impose interest and penalties is an important part of any tax system. Good international practice allows a separate interest charge and late payment penalty to be imposed because interest and penalty serve different purposes. A practical advantage of such an approach is that there may be circumstances when it is appropriate to remit a penalty but the imposition of interest should be maintained. Having the power to waive penalties or interest recognizes that, despite best efforts, circumstances may exist where a taxpayer is not able to file or pay on time. In Canada, for example, the substantive law gives the Minister of National Revenue the discretion to waive or cancel all or any portion of any penalty or interest otherwise payable under the tax law. For certainty and transparency, administrative guidelines set out how this discretion is used. This is also the case in Belgium, for instance, where the tax administration exercises wide discretion to remit late payment interest in "exceptional circumstances" subject to administrative guidelines and, ultimately, under judicial control.

\section{Recovery of Interest}

Late payment interest should become payable in respect of the late payment of any amount that is treated as "tax" as defined under the tax law. This should include 
withholding tax, so that a withholding agent who fails to pay withholding tax by the due date should also be liable for interest in respect of the late payment. However, it is also common for the tax law to be designed and drafted such that any interest that is payable by a withholding agent in respect of the late payment of withholding tax remains a personal liability of the withholding agent. This is achieved by prohibiting the withholding agent-by law or based on general principles-from being able to recover the interest amount from the recipient of the income. This is justified on the basis that the late payment is due to the culpability of the withholding agent, and not the payee with the primary tax liability in relation to which the withholding tax applies. This is also a feature of the sample generic provision for late payment interest in Appendix A.

\section{BEST PRACTICE DESIGN FEATURES FOR TAX PENALTY REGIME}

\section{A. Classification of Sanctions}

\section{Administrative versus criminal sanctions}

Many tax jurisdictions provide for both administrative and criminal tax penalties, and there are good reasons for doing so. The imposition of administrative penalties on non-compliance cases that are of a less egregious nature enables such cases to be taken out of the criminal justice system, thus easing the burden on the criminal courts and ensuring faster and more efficient resolution of such cases. Also, administrative offences typically require a lower standard of proof than criminal offences and therefore can have a greater deterrent effect as non-compliant behaviors are penalized more consistently and predictably. However, criminal sanctions and administrative sanctions are not mutually exclusive, and it is generally possible for a taxpayer to be liable to both administrative and criminal sanctions in relation to a single act of non-compliance. However, depending on the individual circumstances of the country concerned including its legal tradition, legal frameworks may prohibit the imposition of an administrative penalty-in particular where it is punitive in nature-in circumstances where a taxpayer has been convicted and faced criminal sanctions in respect of the same act to which the administrative penalty would otherwise apply, and vice versa.

\section{Administrative penalties should be designed with} regard given to the underlying tax assessment system. Given that most tax systems have now moved to a selfassessment system, where tax assessments are based on the tax filings or returns prepared and lodged by the taxpayer, an administrative penalty regime should also be designed to support voluntary tax compliance. In this regard, an administrative penalty regime provides a simpler and more cost-effective approach to achieving compliance than otherwise seeking to prosecute offences.

\author{
Administrative sanctions are most appropriate \\ for addressing non-compliant behaviors that are \\ easily detectable and in situations where they can be \\ consistently enforced. These include: \\ - Failure to file returns or other requested information \\ at all/in a timely fashion; \\ - Failure to file returns accurately; \\ - Failure to pay taxes at all/in a timely fashion; \\ - Failure to register with tax authority; and \\ - Failure to keep records, including invoices.
}

\section{An administrative penalty regime should conform to the following design principles:}

- Be easily understood by taxpayers and easily administered by the tax authorities;

- Be equitable and fair, for instance by treating taxpayers equally; applying penalties consistently for breaches of similar tax obligations; imposing penalties uniformly in respect of all taxation laws; provide rights of review; and be imposed having regard to any mitigating facts and circumstances;

- Be proportionate, for instance by providing increased penalties based on the culpability of the taxpayer, and by taking into account the level of harm caused by the non-compliance; and

- Be effective, by discouraging non-compliance while maintaining proportionality and fairness. Penalties could also be graduated and take into account the taxpayer's effort to correct any initial non-compliance (such as through reward features), provided the regime does not become too complex to understand and administer.

Criminal sanctions, on the other hand, should only be reserved for serious infractions. Examples of cases where criminal sanctions would be appropriate include 
tax fraud or evasion and obstructing tax officials in carrying out their duties. Certain acts or behaviors that facilitate or are indicative of fraud or evasion-such as falsification of documents-could also be made a criminal offence, without the need to separately prove fraud or evasion. Bribery and corruption are typically subject to criminal sanctions.

\section{Infractions of tax legislation may be subject to} administrative penalties, criminal penalties, or both. There are no universally correct answers as to which is the most appropriate mechanism to use in each case-different countries subject different infractions to administrative or criminal penalties, or both. Several considerations should inform the decision whether to impose administrative penalties, criminal sanctions, or both. These include:

- Administrative penalties are easier to apply, since they are within the tax authority's control;

- Administrative penalties are less expensive to impose than criminal sanctions;

- Administrative penalties tend to be used for lowerimportance infractions;

- Criminal sanctions tend to be used for intentional actions of a taxpayer that deliberately, and in a way that reflects disregard for the law, undermine the integrity of the tax system;

- Administrative penalties are generally used to support compliance, whereas criminal sanctions are generally used to punish behavior that undermines public authority; and

- The result for the taxpayer of an administrative penalty is generally a fine, while the result of a criminal sanction may include imprisonment, in addition to reputational damage from negative publicity typically associated with criminal prosecution.

The distinction between behavior that ought to be sanctioned (only) by administrative sanctions and that for which criminal sanctions are (also) appropriate is not always clear. For example, a taxpayer who has repeatedly failed to file tax returns with an intention to evade tax should be subject to criminal sanctions instead of administrative sanctions for failure to file returns. In such cases, it may be possible to legislate a rebuttable presumption of intent to evade tax if the taxpayer has not filed tax returns for a certain number of reporting periods.
Monetary versus non-monetary sanctions

Administrative and criminal sanctions can be monetary and/or non-monetary. Monetary sanctions involve the payment of additional amounts of money to the tax authority for non-compliance. Under a simplified rational choice theory, a taxpayer should logically refrain from engaging in non-compliance behavior if such behavior is accompanied by a monetary sanction which increases the effective amount payable to the government.

However, monetary sanctions may not always be effective in achieving the goal of deterrence. Monetary sanctions might be viewed as part of the cost of paying taxes and thus indistinguishable in the minds of some taxpayers, particularly if the amount of monetary sanction is insufficient to be an effective deterrent. Some taxpayers may also place more value on other things of greater economic or personal significance-such as the ability to conduct a certain type of business or profession, and reputation - than the amount of a monetary sanction. Monetary sanctions are also less effective against taxpayers who are insolvent, do not hold any property in the jurisdiction, or otherwise are persons against whom a money judgment cannot be effectively enforced.

The object of non-monetary sanctions is to encourage tax compliance by the deprivation of something more valued by the taxpayer than money. Common examples of non-monetary administrative sanctions include suspending business or professional licenses of errant taxpayers, imposing travel restrictions, naming and shaming of recalcitrant taxpayers, and denying public service employment or contract opportunities.

\section{Criminal conviction is a specific form of} non-monetary sanction. A criminal record can have a real cost on a person, which could include the denial of benefits and opportunities-for instance, it can impact a person's employment and ability to travel internationally - and could be more effective than monetary sanctions for certain types of taxpayers. Conversely, in jurisdictions where the social and reputational costs of conviction are low, criminal sanctions may not be as effective. 


\section{B. Adequacy and Effectiveness of Sanctions}

\section{Common penalty framework}

across different tax types

There should be a common penalty framework that applies across different tax types in a tax jurisdiction.

A single framework should apply across all tax types to ensure that identical acts of non-compliance are punished consistently regardless of tax type. This facilitates application of penalty provisions by the tax authority. From a fairness perspective, there is also merit in the argument that all taxes are dues payable to the government budget, and therefore, there should not be a big difference in sanctions for failures to comply with tax obligations solely on grounds of tax types.

\section{Proportionality}

As a general rule, the severity of a penalty should be commensurate with the degree of culpability of the taxpayer. The penalty regime should be carefully calibrated to ensure that it achieves the dual objectives of deterrence and fairness. On the one hand, penalties should not be so low that taxpayers are not incentivized to comply with their tax obligations. On the other hand, penalties should not be so severe that it results in increased corruption-particularly where the tax authority is prone to corrupt practices-and unfairness-if the sanctions are not consistently applied to all offending taxpayers due to weakness in detection or enforcement, or are simply so high that they are effectively unenforceable. Culpability as well as mitigating factors should be taken into account in determining the appropriate level of penalties.

\section{Sample generic provisions that take into account} culpability and mitigating factors in determining the level of administrative penalties arising from a false or misleading statement made by a taxpayer are set out in Appendix B. The sample generic provisions cover a range of circumstances, including cases where a false or misleading statement gives rise to underpaid tax or an overclaimed refund. It also applies where the false or misleading statement does not directly result in an underpayment of tax, which is consistent with the increasing trend towards imposing administrative penalties to encourage taxpayer compliance with respect to pure reporting obligations within the broader context of moving towards greater exchange of informationboth domestically and internationally. However, these sample provisions are general in nature and simplified. Importantly, they do not take into account the individual circumstances of any particular tax system. The ultimate form of any administrative penalty provision to be adopted by any given country would need to take into account the specific legal tradition and systemincluding any constitutional limitations-as well as the political and administrative structure and fiscal policies of the country concerned.

\section{Designing monetary sanctions in general}

Monetary sanctions can broadly be designed in three ways.

(a) The penalty can be a fixed monetary amount that is applied to all taxpayers ( " "fixed penalty"). This approach is most appropriate where the infraction is basic and where it is important for the tax authority to be able to quickly and easily impose the penalty.

(b) The penalty can be percentage based, for example, as a percentage of tax saved or of the taxpayer's total income ( "percentage penalty"). This approach is most appropriate where a fixed, smaller penalty would not be appropriate or effective in promoting compliance by larger taxpayers.

(c) The penalty can be graduated so that it increases depending on the culpability of the taxpayer, including the taxpayer's repeated disregard for the provision (a "graduated penalty"). This approach is most appropriate where the infraction involves varying degrees of culpability by the taxpayer or where the taxpayer may engage in the inappropriate behavior repeatedly.

\section{Monetary penalties should be easy to calculate and should be linked to the amount of tax underpaid (or refund overclaimed), where appropriate. It is common for tax laws to provide for monetary sanctions as a percentage of the amount of tax underpaid or paid late (sometimes with a minimum and/or a maximum). Additional penalties are usually payable for underpayment in more blameworthy cases such as willful evasion, fraud or reckless indifference. Such additional penalties are typically provided for through a graduated scale of penalties referable to the amount of tax underreported and the culpability of the taxpayer, with no penalty where the taxpayer has taken reasonable care or has a reasonable excuse for the underreporting, and different brackets for percentages of the amount of tax underreported based on the egregiousness of the taxpayer's behavior.}




\section{Monetary tax penalties can also be designed as a hybrid model incorporating a combination of the} above design features. For example, in the case of late payment penalties (as distinct from underpayment penalties), some jurisdictions like the UK have adopted-or are considering adopting-a hybrid model where late payment penalties are calculated as a combination of: (i) an element charged based on a percentage of the tax that is not paid by the due date; and (ii) an element charged in a similar way to interest, with this second element being in addition to late payment interest (discussed above). ${ }^{4}$ Further, a grace period to make the late payment of the tax due (e.g. of up to 15 days) could also be considered before the late payment penalty becomes payable to provide some flexibility to taxpayers that need to make arrangements to pay without creating, in effect, a further second late payment. However, accommodating additional design features or greater flexibility should be balanced against the need to maintain simplicity as well as fairness to those taxpayers that pay on time.

In some jurisdictions, the tax penalty regime has been specifically designed and structured in a manner that first sets a base penalty amount, which is then subject to predetermined increasing and/or reducing adjustments. These predetermined adjustments are specifically designed for the purpose of increasing the effectiveness of the penalty regime by discouraging non-compliance but still ensuring that the regime is transparent, proportionate and fair. Penalties could also be graduated and take into account the taxpayer's effort to correct any initial non-compliance (such as through reward features), provided the regime does not becomes too complex to understand and administer. This is the case, for instance, in Australia and South Africa; the sample administrative penalty provision in Appendix B also exhibits some of these features. Common examples where increasing predetermined adjustments are made include:

- The taxpayer took steps to obstruct the revenue authority in carrying out their duties, such as:

- Failure to supply or delay in supplying information;

- Providing false or misleading information or documents; and

- Destroying records;

${ }^{4}$ See, for example, Making Tax Digital: interest harmonization and sanctions for late payment, UK HMRC, December 1, 2017.
- Non-disclosure by the taxpayer after becoming aware of an incorrect tax position; and

- A second (or further repeated) application of the same penalty provision.

Common examples where decreasing predetermined adjustments are made include:

- Position taken by the taxpayer was consistent with advice received from the tax authority;

- The taxpayer relied on existing administrative practice of the tax authority;

- The taxpayer acted consistently with a statement in existing publications/guidelines approved by the tax authority; and

- The taxpayer made a voluntary disclosure before a tax audit or examination was initiated or before a request for information was received. Graduated adjustments could be considered depending on the timing of the voluntary disclosure in the context of an audit cycle such as: (i) before an initial intervention by the tax authority (which entitles the taxpayer to the largest decreasing adjustment); (ii) within a reasonable time after that intervention (smaller decreasing adjustment); or (iii) while the audit is ongoing but before it is finally concluded (even smaller decreasing adjustment).

In other jurisdictions, the tax authority can make more nuanced administrative penalty decisions on a case-by-case basis through the exercise of broader discretionary powers. Such more extensive discretionary powers would enable the tax authority to impose a percentage uplift or reduction for aggravating circumstances-such as hindering the tax authorityor mitigating circumstances-such as in relation to circumstances outlined in the previous paragraph. However, such broad discretionary powers should be exercised consistently and fairly to ensure that taxpayers perceive the tax authority as being fair and just in doing so. A negative perception of the tax authority in exercising its powers could lead to decreased compliance by taxpayers. To promote and ensure consistent application of such powers, it is good practice for the tax authority to promulgate clear and transparent guidelines on the circumstances in which it will increase or decrease the penalties payable, as well as the limited circumstances in which it will consider a remission of penalties-and carefully adhere to those policies. This is the case, for instance, in Belgium and the Netherlands. 
Regardless of the specific design and structure of the penalty regime it is common for tax administrations to have some general discretion to waive all or part of the penalties imposed. This discretion can be designed to be exercised at the taxpayer's request or at the own initiative of the tax authority. However, this discretion should always be applied in the light of the following considerations:

- The relevant facts and circumstances of the individual case;

- The overall purpose of the penalty provision, which is generally to encourage taxpayers to exercise reasonable care in complying with their tax obligations-so a penalty might appropriately be waived if reasonable care has been taken;

- The need to promote consistency of treatment; for instance, penalties should not be remitted without cause, arbitrarily, or as a matter of course which would produce unfair outcomes; and

- Where a penalty has been waived, written notice should be provided to the taxpayer that confirms the waiver.

The exercise of discretionary powers to vary the amount of penalties imposed or to waive all or part of the penalties should also be subject to internal and external oversight to ensure consistency, and any form of inappropriate exercise of powers should be robustly addressed. For example, any exercise of discretionary power should be authorized by one or more officials of appropriate seniority, determined by the amount of penalties increased or reduced. Cases involving the waiver or reduction of penalties should be subject to internal and external audits, and the findings should be reported and published on a regular basis. Tax officials found to have abused such powers of discretion should be subject to disciplinary actions and/or criminal sanctions. These safeguards should be provided for in the tax administration law or tax administration provisions in the substantive tax laws, or in the by-laws of a semiautonomous tax authority as appropriate. Finally, taxpayers should be entitled to appeal penalty decisions.

Flat or fixed amount penalties may be suitable for behavior that has an indirect connection with the underpayment of tax. An example of such behavior would be the failure to file a required document. Such behavior does not directly result in-or have a direct link with-the underpayment of taxes and therefore it would be difficult to use the underpaid amount (if any) as a benchmark for the determination of penalties. However, a flat or fixed amount penalty can still be designed by having regard to the amount of the taxpayer's taxable income for the preceding year of assessment. This design feature can help to ensure that the penalty remains proportionate to the size of the taxpayer to ensure the penalty is effective. The fixed penalty regime in South Africa, for instance, has this feature.

Monetary tax penalties should generally have the same status as tax debts. This ensures that the tax authority can access its regular suite of enforcement and collection powers in relation to tax penalties imposed, with interest accruing on unpaid amounts. Monetary tax penalties should also continue to be effective, notwithstanding for instance the bankruptcy of the tax defaulter. ${ }^{5}$

\section{Designing non-monetary sanctions in general}

Non-monetary sanctions are most appropriate where a fine would not be effective in promoting compliance. In designing such sanctions, it is important to properly identify the types of non-monetary rights and benefits that taxpayers of a particular profile are likely to cherish or value more highly than money, and to limit access to those rights and benefits in case of non-compliance. For example, businesses are likely to place a high value on their ability to carry out their business activities, as well as on their business reputation. Revocation or suspension of business licenses and naming and shaming businesses for non-tax compliance may therefore have a deterrent effect on businesses.

However, care should be taken to ensure that any non-monetary sanctions imposed do not inadvertently impede the taxpayer's ability to pay off tax and other government debts. In the previous example, the revocation or suspension of business license may further hamper the taxpayer's ability to pay the outstanding tax. Other comparable actions such as seizure of assets or temporary closure of business premises can have similar adverse consequences. Similarly, naming and shaming a business can also negatively impact the business' ability to make the profits or to obtain the line of credit necessary for it to pay off the tax debt. One solution might be an ability for the tax authority to suspend revocation or naming-and-shaming on a case-by-case

\footnotetext{
5 The priority of monetary tax penalties and of tax debts more generally in a bankruptcy or liquidation case is a separate issue, which does not fall within the scope of this note.
} 
basis, with the taxpayer undertaking to pay the tax debt within a fixed period of time, failing which the non-monetary sanctions will be imposed.

Another consideration in designing non-monetary sanctions is the fact that such sanctions are likely to be enforced by-or at least require cooperation from-an agency other than the tax authority. As such, it is critical that there is the necessary capacity and infrastructure for interdepartmental or interagency cooperation. For example, any travel restrictions imposed on a taxpayer with outstanding tax debts by the tax authority will need to be enforced by the immigration department. Apart from a legal requirement for immigration officers to recognize and enforce such a restriction order issued by the tax authority, there should be sufficient confidence in the integrity of the immigration department and its officers tasked with enforcing the order. The taxpayer should also have the right to have any such order judicially reviewed, either before it is issued or in a prompt and timely manner immediately afterwards (for instance, within 72 hours) if the law permits such an order to first be issued by the tax authority without prior judicial intervention (for instance, where there is an imminent flight risk).

\section{Additional considerations in}

\section{designing administrative penalties}

Administrative penalties are generally imposed to encourage compliance rather than to punish egregious and improper behavior that undermines the integrity of the tax system. Therefore, the same statute of limitations that applies for reassessment of the taxpayer in the normal context-as opposed to fraud or evasion cases-should apply for the imposition of administrative penalties. If the penalty relates to fraud or evasion, then the period might be extended to match the corresponding period for reassessment in those circumstances.

Taxpayers should be clearly informed of the imposition of an administrative penalty without unreasonable delay, and be afforded a right of review or appeal in relation to the penalty imposed. International good practice, as well as any constitutional, administrative law and other legal requirements as may be applicable to each jurisdiction, requires that taxpayers receive notice in writing about the imposition of the penalty and be provided with a statement explaining why the penalty was imposed. The due date for payment of the penalty should be clearly stated and the taxpayer should be notified if interest applies to late payments. Finally, the taxpayer should be given notice about what appeal rights are available to object to the imposition of the penalty. These aspects can become critical to the effectiveness of the tax penalty regime and are influenced by broader human rights developments which can apply at each level of the imposition, collection, enforcement and dispute resolution process embedded in such a regime. The risk of infringing upon any relevant fundamental rights of taxpayers becomes greater when the purpose of the tax penalty regime is to have a deterrent and punitive effect, particularly when greater powers are also granted to the tax administration in order to enforce and collect the penalty imposed. The legal design considerations relating to human rights developments are generally more focused on ensuring fair treatment of taxpayers by the tax administration and preserving their access to an appropriate judicial process. In this regard, various Articles of the European Convention of Human Rights, including Article 6 (right to a fair trial), have been relied upon, where applicable, to challenge the rules and procedures in tax matters. For example, in the context of imposing more severe tax related penalties of deterrent effect, the penalty regime and associated processes would typically need to preserve the right to a reasonable resolution of the matter while also maintaining appropriate access to judicial review. This is also relevant to the discussion on designing criminal sanctions below.

\section{Additional considerations in designing criminal sanctions}

Tax crimes typically involve an abuse of the tax system through intentional and dishonest behavior, with the aim of obtaining a financial benefit. Tax crimes commonly include tax fraud and tax evasion. A distinction needs to be drawn between tax crimes on the one hand, and tax avoidance or tax minimization/ mitigation on the other hand. Tax avoidance or tax minimization/mitigation do not commonly involve criminal acts.

As a general rule, it is preferable for tax crimes to be specified in the tax laws and to be prosecuted by the relevant authority responsible for public prosecutions. Grouping all sanction provisions-administrative as well as criminal-enhances transparency and promotes coherence of the sanctions policy. While in most jurisdictions tax crimes are prosecuted by the relevant 
authority for public prosecutions, the tax authority should still have the authority to review and recommend cases for criminal prosecution given its specialist knowledge in this often-complex area of criminal law. In terms of procedure, the general rules of criminal procedure of that jurisdiction should apply to tax crimes. In addition to misconduct arising from a taxpayer's own actions, criminal prosecution could also arise in the following circumstances:

- Assisting someone else to evade tax (aiding and abetting, or conspiracy to defraud);

- Breach of confidentiality of taxpayer information; and

- Corruption of tax officials.

Custodial sanctions entailing the deprivation of individual freedom might be more effective against delinquent taxpayers against whom other types of sanctions are ineffective. However, there might be difficulties in applying a custodial sentence to a legal person, whose separate legal personality often affords protection against personal liabilities to its members and officers. One option is to impose derivative liability on directors for the commission of an offence by the company, so that directors can be subject to custodial sanctions if the company is found to have committed a tax crime in circumstances where the act was committed with the director's consent or knowledge. However, such an option may not be effective in relation to legal entities if the corporation laws of the jurisdiction have no local director requirement.

Other types of criminal penalties may also be imposed and other legal consequences may arise as a result of criminal prosecutions. These could include:

- Imposition of security bonds;

- Community service orders;

- Fines;

- Additional penalties; and

- Other consequences such as seizure of assets under proceeds of crime provisions, including under antimoney laundering legislation.

To avoid overburdening the criminal justice system, some jurisdictions provide for an ability for the tax authority to compound offences by giving the taxpayer the option to pay money in lieu of his prosecution. However, this raises concerns of horizontal fairness as one may or may not have a criminal record for the same offence depending on prosecutorial discretion in compounding the offence. This problem may be mitigated by having clear guidelines on the circumstances under which an offence may be compounded.

\section{Other factors affecting effectiveness of sanctions}

There are factors other than the legal design of sanctions that may affect their effectiveness in deterring unwanted behavior, some of which are listed briefly here. Taxpayers must first be able to understand their legal obligations and the consequences of non-compliance, so tax laws and regulations should be drafted in a modern, easy-to-read manner. ${ }^{6}$ Tax authorities must also be confident and consistent in applying the penalty provisions. Certainty of sanction is necessary to ensure that taxpayers do not view the system as arbitrary and unfair. Unfairness in application of sanctions discourages compliance. Robust audits as well as consistent and effective enforcement efforts by the tax authority result in high probability of punishment, thereby encouraging compliance. This may be further enhanced by publicizing cases of punishment where the tax authority has demonstrated strong abilities to detect non-compliance and apply sanctions.

\section{A number of common compliance strategies and tools} are also regularly employed to detect cases of fraud, all of which usually involve some legal underpinnings. These include:

- International information sharing (such as through exchange of information or EOI), joint operations and mutual assistance (for instance, intelligence gathering, investigations and audits with international tax administrations using bilateral tax treaties, multilateral convention on mutual administrative assistance in tax matters etc.);

- Inter-departmental or inter-agency cooperation (for instance, through domestic EOI or intelligence sharing, such as with a Financial Integrity Unit or FIU);

- Analytical detection models (for instance, by identifying outliers or anomalies with respect to information disclosed in tax returns, or information supplied to other regulators);

\footnotetext{
6 See IMF and Organization for Economic Co-operation and Development (OECD), 2017, "Tax Certainty" IMF/OECD Report and, 2018, "Update on Tax Certainty" IMF/OECD Report for the G20 Finance
} Ministers. 
- Data matching (for instance, by comparing taxpayer data against information reported by investment entities, financial institutions and other regulated entities to the tax authority or to other regulators), including use of big data;

- Risk profiling (for instance, by focusing on areas that present a higher risk to revenue, including offshore secrecy arrangements, refund fraud, identity crime and organized crime);

- Random audits/tax verifications; and

- Community reporting (such as whistle-blowers, tip-offs, etc.).

\section{Voluntary Disclosure Programs} Voluntary disclosure programs (VDPs) have become increasingly popular with tax administrations in recent years-in particular as access to taxpayer information both from domestic and foreign sources increases. The objective of VDPs is to offer taxpayers substantial reduction of tax penalties in exchange for voluntarily disclosing past non-compliance.

\section{Any reduction in penalties under a VDP should} not extend to interest payable by a participant. As discussed earlier, interest is compensatory in nature as it seeks to compensate the government for the deprivation of the earning capacity of the amount underpaid, and therefore should not, as a general rule and a matter of principle, be reduced or waived.
Penalty reduction should only be granted where disclosure is genuinely voluntary. This is because the objective of a VDP is to facilitate the collection of taxes that would otherwise not be uncovered by way of audit or investigation. In other words, penalties should not be reduced if taxpayers have come forward only upon or after investigation or audit.

A VDP should be designed to ensure that taxpayers are adequately incentivized to come forward and disclose their past failures. First, the tax penalties as provided under the laws, as well as the reduction in penalties offered under the VDP, must be substantial in order for it to be sufficiently attractive for taxpayers to step forward. However, penalties should not be completely removed for a participant under a VDP to ensure horizontal fairness with compliant taxpayers. Second, there must be credible and effective ongoing audit and enforcement efforts by the tax authority. Taxpayers will not be inclined to participate in the VDP if there is no reasonable chance of being caught for their previous non-compliance. Third, the VDP should be well publicized so that taxpayers are aware of the opportunities and advantages thereunder.

Failure to make a voluntary disclosure should be taken into account in determining the culpability of a taxpayer upon subsequent discovery of any irregularities or errors. In a jurisdiction where the tax authority exercises administrative penalty discretion, such failure of a delinquent taxpayer to avail of the VDP should be seen as an aggravating factor, unless there are good reasons why the taxpayer was unable to participate in the VDP. 


\section{APPENDIX A \\ SAMPLE LATE PAYMENT INTEREST PROVISION}

Drafting note: The title "Director-General" is used for the purposes of the sample provisions in both Appendix A and Appendix B but this title should be substituted with the actual designation used in a particular country such as "Commissioner" if that is the title that applies.

\section{Late payment interest}

(1) Subject to subsection (8), a person who fails to pay tax on or before the due date for payment is liable for late payment interest at the prescribed rate on the amount unpaid calculated for the period commencing from the date the payment was due to the date the payment is made.

(2) When calculating interest under subsection (1) in respect of an adjusted assessment, the due date for the payment of the tax is the date on which tax became payable under the original assessment without regard to any extension of time to pay that may have been granted.

(3) Any interest paid by a person under subsection (1) must be refunded to the person to the extent that the amount to which the interest relates is found not to have been payable.

(4) Late payment interest payable by a person in respect of withholding tax is borne personally by the person and is not recoverable from any other person.

(5) Interest payable under this section is computed on a daily compounding basis.

(6) The Director-General may serve a taxpayer liable for late payment interest with notice of the amount of late payment interest payable by the taxpayer and the due date for payment.

(7) A notice of the amount of late payment interest payable by a taxpayer may be included in any other notice, including a notice of a taxation assessment, served by the Director-General on the taxpayer.
(8) When-

(a) the Director-General notifies a taxpayer in writing of the taxpayer's outstanding tax liability under a tax law (including in a taxation assessment); and

(b) the taxpayer pays the balance notified in full within the time specified in the notification (including late payment interest payable up to the date of the notification), late payment interest does not accrue for the period between the date of notification and the date of payment.

(9) Interest payable under this section is in addition to any administrative penalty imposed under sections

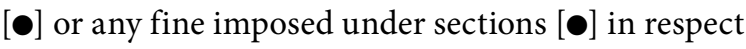
of the same act or omission.

(10) The total amount of late payment interest payable by a taxpayer in respect of an unpaid tax liability must not exceed the amount of the liability.

(11) In this section, "tax" includes customs duty and excise tax imposed under the Customs legislation but does not include late payment interest. 


\section{APPENDIX B \\ SAMPLE ADMINISTRATIVE PENALTIES PROVISIONS}

\section{Tax shortfall penalty}

(1) This section applies where-

(a) a person makes a statement to a taxation officer that is false or misleading in a material particular or omits from a statement made to a taxation officer any matter or thing without which the statement is false or misleading in a material particular; and

(b) the tax liability of the person, or any other person, computed on the basis of the statement is less than it would have been had the statement not been false or misleading (the difference being referred to in this section as the "tax shortfall").

(2) Subject to subsections (3) and (4), a person to whom this section applies is liable for a tax shortfall penalty equal to-

(a) when the statement or omission was made knowingly or recklessly, $75 \%$ of the tax shortfall; or

(b) in any other case, $20 \%$ of the tax shortfall.

(3) The amount of a tax shortfall penalty imposed under subsection (2) on a person is increased by-

(a) 10 percentage points when this is the second application of this section to the person; or

(b) 25 percentage points when this is the third or a subsequent application of this section to the person.

(4) The amount of a tax shortfall penalty imposed under subsection (2) on a person is reduced by 10 percentage points when the person voluntarily discloses to the Director-General the statement or omission to which this section applies before the earlier of-

(a) discovery by the Director-General of the tax shortfall; or

(b) the commencement of an audit of the tax affairs of the person to whom the statement relates.
(5) No tax shortfall penalty is payable under subsection (2) when-

(a) the person who made the statement did not know and could not reasonably be expected to know that the statement was false or misleading in a material particular;

(b) subject to subsection (6), the tax shortfall arose as a result of a taxpayer taking a reasonably arguable position on the application of a revenue law to the taxpayer's circumstances in lodging a self-assessment return; or

(c) the failure was due to a clerical or similar error, other than a repeated clerical or similar error.

(6) A position taken by a taxpayer in making a selfassessment that is contrary to a public ruling in force is not regarded as a reasonably arguable position for the purposes of subsection (5)(b).

(7) Nothing in subsection (5) prevents the imposition of late payment interest in respect of a tax shortfall when the tax is not paid by the due date for payment.

(8) For the purposes of this section, a statement made to a taxation officer includes a statement made, in writing or orally, in any of the following circumstances-

(a) in an application, certificate, declaration, notification, tax return, objection, or other document lodged under a revenue law, or a Customs entry lodged under the Customs legislation;

(b) in information furnished under a revenue law;

(c) in a document provided to a taxation officer otherwise than pursuant to a revenue law;

(d) in an answer to a question asked of a person by a taxation officer;

(e) in a statement to another person with the knowledge or reasonable expectation that the statement would be passed on to a taxation officer. 


\section{False or misleading statement penalty}

(1) This section applies where-

(a) a person makes a statement to a taxation officer that is false or misleading in a material particular or omits from a statement made to a taxation officer any matter or thing without which the statement is false or misleading in a material particular; and

(b) either-

(i) there is no tax shortfall; or

(ii) a tax refund for the person, or any other person, computed on the basis of the statement is more than it would have been had the statement not been false or misleading (the difference being referred to in this section as the "excess refund").

(2) Subject to subsection (3), a person to whom this section applies is liable for a false or misleading statement penalty equal to-

(a) in the case where there is no tax shortfall -

(i) when the statement or omission was made knowingly or recklessly, [1\% of the person's total taxable income for the preceding year of assessment or $\$ 1,000$, whichever is higher]; or

(ii) in any other case, $[0.5 \%$ of the person's total taxable income for the preceding year of assessment or $\$ 500$, whichever is higher]; or

(b) in the case of a tax refund,

(i) when the statement or omission was made knowingly or recklessly, $75 \%$ of the excess refund; or

(ii) in any other case, $20 \%$ of the excess refund.
(3) No false or misleading statement penalty applies when-

(a) the person who made the statement did not know and could not reasonably be expected to know that the statement was false or misleading in a material particular;

(b) subject to subsection (4), the tax refund arose as a result of a taxpayer taking a reasonably arguable position on the application of a revenue law to the taxpayer's circumstances in lodging a self-assessment return; or

(c) the failure was due to a clerical or similar error, other than a repeated clerical or similar error.

(4) A position taken by a taxpayer in making a selfassessment that is contrary to a public ruling in force is not regarded as a reasonably arguable position for the purposes of subsection (3)(b).

(5) Section 1(8) applies in determining whether a person has made a statement to a taxation officer. 
This page intentionally left blank 
The tax law function within the Legal Department of the IMF is responsible for providing high-quality legal advice and training in relation to taxation to the IMF's member countries in the context of technical assistance (TA), capacity development/ training, IMF surveillance, IMF financial assistance programs and Financial Sector Assessment Programs (FSAPs).

Tax Law IMF Technical Note series reflects the views of the tax counsels of the Legal Department with respect to a topical tax law issue, drawing on their experience in advising the wider IMF membership in relation to tax law design and drafting. 